\title{
What is the real Hormotila? (Chlorophyceae)
}

\author{
Daniel E. Wujek ${ }^{1, *}$ and Michael J. Wynne ${ }^{2}$ \\ ${ }^{1}$ Department of Biology, Central Michigan University, Mt. Pleasant, MI 48859, USA \\ ${ }^{2}$ University of Michigan Herbarium, 3600 Varsity Drive, Ann Arbor, MI 48108, USA
}

It is shown by the heterogenous nature of Borzi's description and illustrations that Hormotila mucigena Borzi, the generitype of Hormotila, should be redefined. Borzi's original description and accompanying illustrations of Hormotila (constituting the protologue) correspond to a minimum of five distinct genera of green algae. Two distinct concepts of the genus have persisted over the years. The genus has become based on a combination of palmelloid and physiologically stressed forms of two of the component algae. Our understanding of the genus is further confused by the incorporation of unrelated unicellular and colonial coccoid forms. There are only one or two distinctive attributes that would allow the selection of any one of the five forms as representing the genus and species. One of Borzi's original figures is proposed to redefine the original species of the genus, Hormotila mucigena.

Key Words: Chlorophyceae; Hormotila; H. mucigena; nomenclature

\section{INTRODUCTION}

Antonino Borzi's (1852-1921) (De Toni 1922, Stafleu and Mennega 1993) study of algae was based on field collections and examination of these field collections over a period of time. Collections were made, kept in glass containers in a window and replenished with river water and well water as needed. Observations were carried out over an interval of time. His cultures were most likely a mixture of algal forms.

Borzi's publications (1883), with faithful illustrations, attest to the fact that his taxonomic concepts were based on multiple taxa. We make this assertion based upon comparing his figures of Hormotila mucigena to currently accepted taxonomic understanding of this group of green algae. Although many of the genera that he described are recognized in current taxonomic works, in the light of present-day knowledge his original publications damage the integrity of some of his genera, Hormotila being an example.

\section{MATERIALS AND METHODS}

According to Koster (1969), the algae in Borzi's herbarium, which was left to the Istituto Botanico [now the Herbarium Mediterraneum Panormitanum], Palermo (PAL), are reported to be missing. Koster's information proved to be incorrect. Ferreri (1998) published on the historical algal collection of Herbarium Mediterraneum, and Ferreri (1998, p. 184) cited “Hormotila gelatinosa Borzi.” Dr. Anna Maria Mannino kindly located the specimen in PAL (Fig. $1 \mathrm{~A} \& \mathrm{D})$, with the name "Hormotila gelatinosa Borzi." Despite the difference in the epithet [gelatinosa versus $\mathrm{mu}$ cigena], all of the other label information (location, date, and collector) is in agreement with the protologue. Borzi considered calling his new species Hormotila gelatinosa but later validated the name Hormotila mucigena, forgetting to change the name on the label. Annotation labels were attached by "Giaccone-Sortino-Sportino" with the name Hormotila mucigena (Fig. 1B \& C). The packet contains a dust-like sample presumably with material used terms of the Creative Commons Attribution Non-Commercial License (http://creativecommons.org/licenses/by-nc/3.0/) which permits unrestricted non-commercial use, distribution, and reproduction in any medium, provided the original work is properly cited.
Received January 10, 2016, Accepted April 16, 2016

* Corresponding Author

E-mail: wujek1de@cmich.edu

Tel: +1-989-774-3227, Fax: +1-989-774-3462 


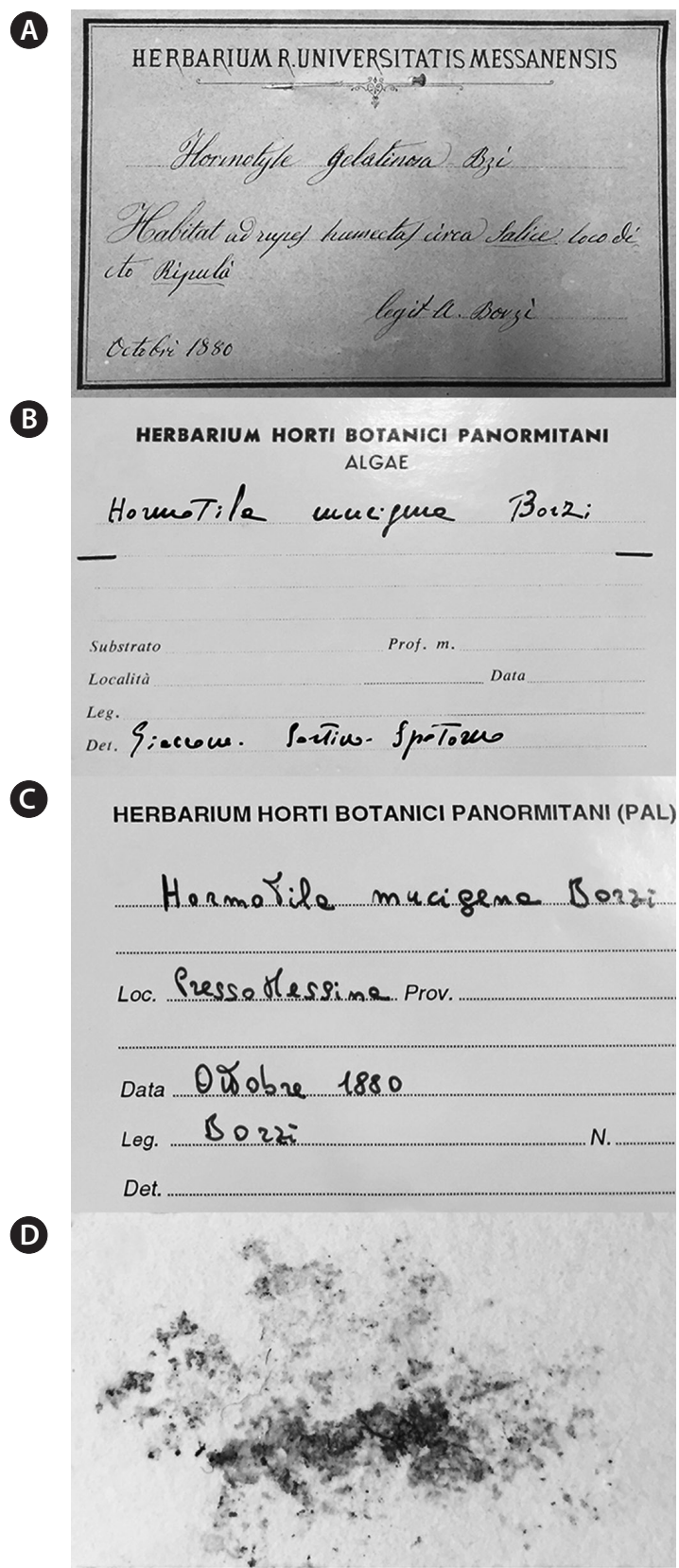

Fig. 1. (A) Original Borzi label. (B \& C) Later annotations. (D) Contents of packet.

by Borzi (Fig. 1D), which we contend was a mixture of algal taxa. This collection represents the holotype.

\section{RESULTS}

The original description of Hormotila mucigena by Borzi (1883) encompassed a number of cellular forms or "conditions" of the algae that appeared in his collections.
Although the early treatment of Hormotila by Wille (1897) included the full array of Borzi's forms in his account of the genus, later workers recognized that the genus was comprised of disparate elements. We make the contention and offer evidence that at least five different forms corresponding to five distinct genera can be interpreted from Borzi's description of Hormotila mucigena. The first form described was an Urococcus-like mass of cells that he likened to Gloecocystis (Fig. 2A \& B). The cells in the masses repeatedly secrete gelatinous sheaths often in a polar fashion so as come to lie at the apex of stratified gel stacks.

Borzi (1883) stated [our translation] in reference to his Figs 1-2 (see Fig. 2A \& B) "Hormotila mucigena, as I said, when examined in the vegetative stage looks like Gloeocystis. However, the texture of the teguments that envelope the cells is very variable; in some cases they become very fluid and their usual concentric stratifications disappear, so they become fused together in an almost amorphous mucilaginous mass, and the whole colony shows the habit of a Palmella. Sometimes, however, the same envelopes become solid differentiating into an annular thickened support as those that are characteristic of the genus Urococcus." This was one of the forms that was subsequently used to identify the genus Hormotila by some phycologists (e.g., Smith 1933, 1950, Skuja 1964, Bourrelly 1966, Bold and Wynne 1978, 1985, Shubert and Gärtner 2015). Smith’s Fig. 57 (1950) was drawn from "a herbarium specimen.” Smith (1950) reported H. mucigena occurring in North America only in California and Iowa. Smith's material was likely based upon specimen No. 1218 in the exsiccata Phycotheca Boreali-Americana (Collins et al. 1905), which was a collection made by W. J. V. Osterhout and N. L. Gardner and said to be "forming a red coating on sticks and stones in an old reservoir, Hayward's, near Oakland, California, Jan., 1904."

Trainor and Hilton (1964) also followed this interpretation of Hormotila when they described H. blennista. It is to be pointed out that Ettl and Gärtner (2013) suggested that $H$. blennista was $H$. mucigena in the sense of Smith (1950).

The second form described by Borzi consisted of a branched-filamentous organization (Fig. 2C). In this form the individual cells round up and secrete tubular formations, with some cells terminating these tubes and other cells remaining in intercalary positions. Thus, the cells come to lie remote from one another (Fig. 2D). For this form, more particularly for cells only partly developed as just described, Borzi described and depicted the release of zoospores and also aplanospores. The zoospores are 


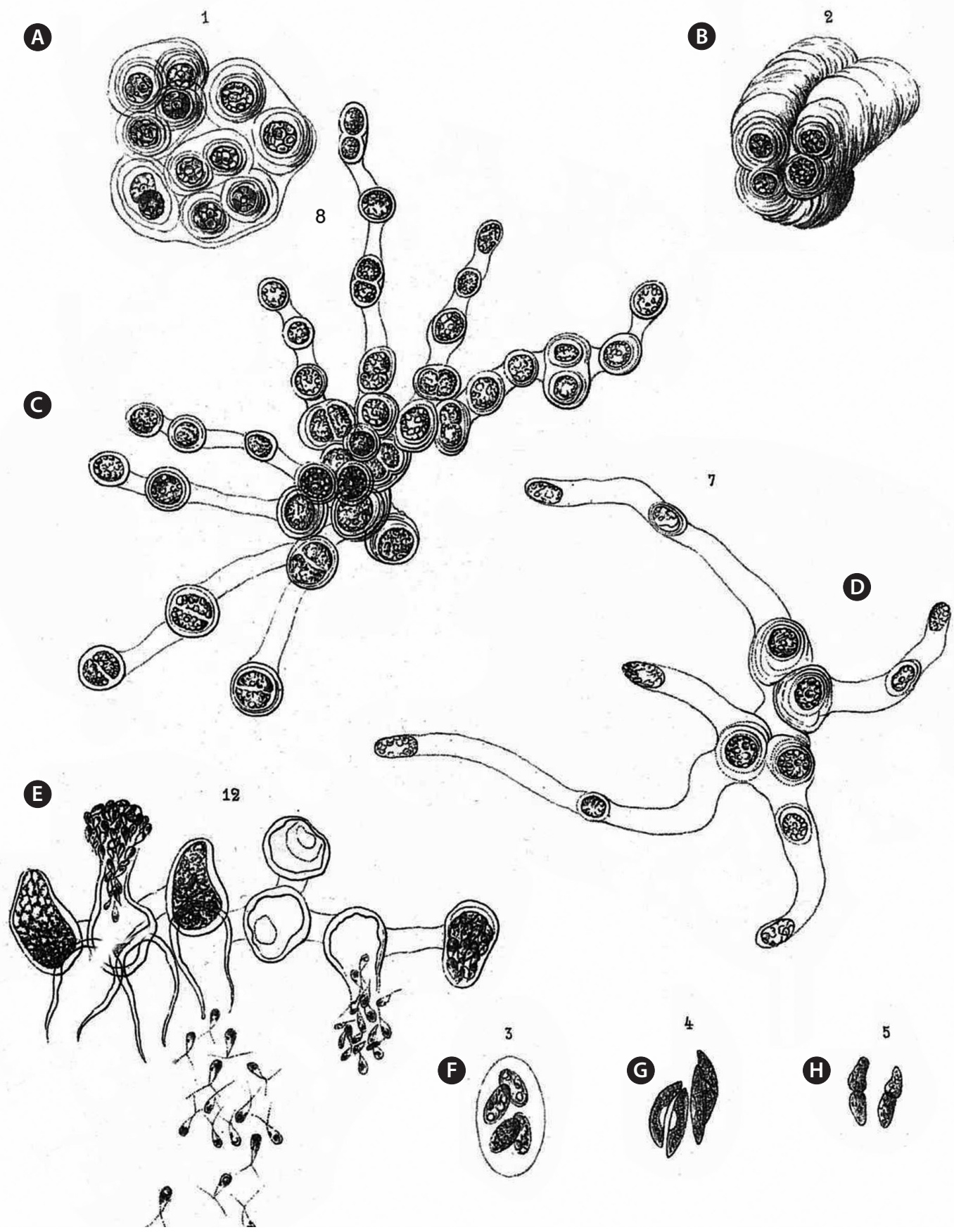

Fig. 2. Borzi's (1883) illustrations from his pls VIII and IX of his collections representing Hormotila mucigena. (A \& B) Urococcus-like mass of cells that were likened to Gloecocystis. (C) Form described with branched-filamentous organization. (D) Cells come to lie remote from each other. (E) Zoospores massed outside of the cell in a vesicle. (F) Colony of cells enclosed by the expanded mother-cell wall much like Oocystis submarina. (G) Lunate cells suggesting Ankistrodesmus convolutus or Quadrigula closterioides. (H) Cells after cleavage suggesting an Elakatothrix, possibly Elakatothrix viridis $(\mathrm{A}-\mathrm{H}, \times 650)$. 
biflagellate and were depicted as being quite metabolic, hence motile. Borzi described this release as en masse, “... per porsum lateralem lihere examinantes...," and his illustration bears this out. The zoospores are massed outside of the cell as in a vesicle (Fig. 2E). Everything about this filamentous form is totally different from the Urococcuslike palmelloid masses discussed above. The only common feature is the secretion of gel, however, in a quite different manner in each case. This branched, filamentous form is the concept used by Lemmermann (1915) to characterize the genus. Lemmermann (1915, Fig. 7a-d) included the production of zoosporangia and zoospores in his concept of Hormotila. This interpretation was followed by Printz (1927), Fritsch (1935), Korshikov (1953), and Bourrelly (1966). Hormotila ramosissima Korshikov, an additional species assigned to the genus by Korshikov (1953) (Lund and Tylka 1987), conformed to this interpretation of the genus as having a branched-filamentous organization.

Chodat (1902) seems to have been the first to cast some doubt on the integrity of Hormotila as a distinct genus by referring to a species of Pleurococcus as having a "Hormotila stage." West (1904) observed what he regarded as $H$. mucigena Borzi from Boston Spa, West Yorkshire, England, saying it "forms an expanded, dull green stratum on the damp surfaces of calcareous rocks." West's Fig. 14 (1904) presents a blend of Borzi's depiction (1883), with cells both in intercalary positions and terminating branched stalks with an indication of gelatinous layers. West's depiction (1904) was repeated by Collins (1909) and John and Tsarenko (2011). According to Hindák (1982), the colonies of $H$. mucigena that he observed were not abundantly ramified but mostly solitary or in pairs or forming small groups.

The filamentous form described and figured by Borzi strongly suggests physiologically stressed development in a minimal or spent medium of what was probably originally a truly branched, filamentous alga. The production of aplanospores that Borzi reported correlates with environmental stress due to development in a minimal or spent medium.

Not included in the description but depicted among the figures labeled Hormotila mucigena are three colonial coccoid algae. Borzi (1883) referred to one to as a colony consisting of four cells enclosed by the expanded mothercell wall (Fig. 2F). This form corresponds to Oocystis and is likely O. submarina Lagerheim. The second colony is a group of four slightly lunate cells in two opposed pairs. It could be a short, lunate Ankistrodesmus such as A. convolutus Corda or a Quadrigula such as Q. closterioides
(Bohlin) Printz (Fig. 2G). The third, Borzi's Fig. 5, suggests an Elakatothrix, possibly Elakatothrix viridis (J. W. Snow) Printz (Fig. 2H) with cells just after cleavage. These colonial forms have nothing to do with either the Gloeocystis form or the branched-filamentous form. They (Borzi 1883, Figs 3-5) are considered to represent unrelated genera of green algae.

\section{DISCUSSION}

The authors believe that the Gloeocystis form and the branched-filamentous form in Borzi's description are two totally different algal genera. The problem then is: What is the real Hormotila mucigena? It is clear that the zoospores that he attributed to the Gloeocystis form of Borzi's Figs 1 and 2 cannot be used to redefine Hormotila. Furthermore, having the Gloeocystis-like group represent H. mucigena is dismissed because it illustrates a "palmelloid" condition that develops in unrelated green algae when growing under certain conditions. Fritsch (1935) has documented how "Palmella-stages" are formed in members of several different orders of green algae, and he also discussed "palmelloid forms" in various unrelated classes of algae.

The genus Urococcus Kützing (1849) has been a "catchall" genus for such gelatinous-colonial forms from the time of its description in the early days of algal microscopy (Collins 1909). With the exception of $U$. insignis (Hassall) Kützing, which was removed from the genus (Smith 1950), the remaining species of the genus have not been identified following their original descriptions. It is quite likely that Urococcus is simply a "form genus" encompassing this palmelloid phase of similar morphology from quite different algal resources. The confusion of at least five generic forms of algae in the characterization of the Hormotila mucigena effectively damages credibility for four of them being the correct basis for H. mucigena, thus leaving only one of the forms (Borzi 1883, Pl. VIII, Fig. 8) being the correct and reliable basis for H. mucigena.

Because biflagellate zoospores were attributed to the Urococcus-like or Gloeocystis-like forms in Borzi's Hormotila (albeit erroneously), the genus Hormotilopsis Trainor and Bold (1953) was erected to delineate a morphologically similar alga on the basis of its distinction being the production of quadriflagellate zoospores.

The situation with Hormotila, then, is as follows:

(1) The agglomeration of five distinct algal genera in Borzi's original description and illustrations of the genus Hormotila mucigena. 
(2) The erroneous attribution to the genus of the zoospores of one of the algal forms.

(3) The basing of the genus (in part) on a palmelloid form.

(4) The confusion of including unicellular-colonial forms to generic forms.

(5) With the exclusion of four of these forms, it is now possible to re-define the species Hormotila mucige$n a$, the basis of the genus Hormotila (based on the single species $H$. mucigena) with the narrow definition of branched-filamentous organization. The figure that conforms to this emended definition of the species is in Borzi's original description (1883, Pl. VIII, Fig. 8). That figure is reproduced in our Fig. 2C. We believe that the characterization of Hormotila mucigena as having a branched-filamentous organization (as shown in Borzi 1883, Pl. VIII, Fig. 8) is the best method to resolve the uncertainty of the nature of the species and thus of the genus.

We propose to clarify the persistent uncertainty about the taxonomic identity of Hormotila mucigena by redefining its vague original description by Borzi and limiting its circumscription to the branched-filamentous organization as depicted by Borzi (1883, Pl. VIII, Fig. 8) (= our Fig. 2C).

Emended description: Thallus of branched filaments. Its environmentally stressed filaments with one to many cells at ends or spread along linear mucilaginous matrix. Matrix wider or thinner than vegetative cells and highly lamellate to smooth. Stressed cells spherical to ellipsoidal, 4-12 $\times 10-20 \mu \mathrm{m}$. Cells uninucleate; chloroplast single and parietal and variable; pyrenoid one or two per cell or absent. Cells mostly green but may become yellow or red with accumulation of carotenoids. Growth by vegetative cell division or spore formation. Asexual reproduction by autospores or biflagellate, naked zoospores or filament fragmentation. Sporangia spherical to elongate and irregular, to $30 \mu \mathrm{m}$ long with up to 64 aplanospores or zoospores released by a tear in sporangium. Zoospores oval to ellipsoid or irregular with apical flagella, 3-11 × 1-7 $\mu \mathrm{m}$, with stigma and contractile vacuoles.

\section{ACKNOWLEDGEMENTS}

We are grateful to Dr. Anna Maria Mannino, Herbarium Panormitanum Palermo, Italy, for her locating Borzi's algal material in PAL. We also thank Dr. Mark B. Edlund of the Science Museum of Minnesota, Marine on St. Croix, Minnesota, for his technical assistance and Dr. John D.
Wehr of the Louis Calder Center, Fordham University, Armonk, New York, for his help in obtaining literature. Special thanks to Dr. Robert Andersen and reviewer \#2 for their valuable input in revising our manuscript.

\section{REFERENCES}

Bold, H. C. \& Wynne, M. J. 1978. Introduction to the algae: structure and reproduction. Prentice-Hall, Inc., Englewood Cliffs, NJ, 706 pp.

Bold, H. C. \& Wynne, M. J. 1985. Introduction to the algae: structure and reproduction. 2nd ed. Prentice-Hall, Inc., Englewood Cliffs, NJ, $720 \mathrm{pp}$.

Borzi, A. 1883. Studi algologici. Saggio di richersche sulla biologia delle alghe. Fasc. I. Gaetano Capra e Co., Messina, 117 pp. [Reprinted in 1996, Edizioni "Naturama", Palermo].

Bourrelly, P. 1966. Les algues d'eau douce I. Les algues vertes. Éditions N. Boubée \& Cie, Paris, 412 pp.

Chodat, R. H. 1902. Algues vertes de la Suisse. PleurococcoïdesChroolépoides. Matériaux pour la Flora Cryptogamique Suisse. Vol. I, Fasc. 3. K-J Wyss, Berne, 373 pp.

Collins, F. S. 1909. The green algae of North America. Tufts College Studies 2:79-480.

Collins, F. S., Holden, I. \& Setchell, W. A. 1905. Phycotheca Boreali-Americana. Fascicle XXV. Malden, MA.

De Toni, G. B. 1922. Necrologio [A. Borzi]. Nuova Notarisia 33:158-159.

Ettl, H. \& Gärtner, G. 2013. Syllabus der Boden-, Luft- und Flechtalgen. 2nd ed. Springer Spektrum, Berlin, 773 pp.

Ferreri, B. M. 1998. La collezione algologica storica dell'erbario Mediterraneo. Naturalista Siciliano, Ser. IV 22:87-227.

Fritsch, F. E. 1935. Structure and reproduction of the algae. Vol. 1. Cambridge University Press, Cambridge, 791 pp.

Hindák, F. 1982. Systematic position of some genera of green algae characterized by the formation of mucilaginous or pseudofilaments colonies. Preslia 54:1-18.

John, D. M. \& Tsarenko, P. M. 2011. Order Chlorococcales sensu stricto. In John, D. M., Whitton, B. A. \& Brook, A. J. (Eds.) The Freshwater Algal Flora of the British Isles: An Identification Guide to Freshwater and Terrestrial Algae. 2nd ed. University of Cambridge Press, Cambridge, pp. 411-418.

Korshikov, A. A. 1953. Pidklas Protokovi (Protococcineae). Viznacik prisnovodnich vodorostej krainskoj RSR. Akad. Nauk USRS. Kiev 5:1-439 (in Ukrainian).

Koster, J. T. 1969. Type collections of algae. Taxon 18:549-559. Kützing, F. T. 1849. Species algarum. F. A. Brockhaus, Lipisae, 
913 pp.

Lemmermann, E. 1915. Tetrasporales. In Pascher, A. (Ed.) Die Süsswasserflora Deutschlands, Österreichs und der Schweiz. Heft 5. Chlorophyceae 2. Gustav Fischer, Jena, pp. 21-51.

Lund, J. W. G. \& Tylka, W. 1987. The freshwater algae of the Ukraine SSR. V. Sub-Class Protococcineae. Vacuolales and Protococcales by O. A. Korshikov. English translation. Bishen Singh Mahendra Pal Singh and Koeltz Scientific Books, Dehra Dun, 439 pp.

Printz, H. 1927. Chlorophyceae. In Engler, A. (Ed.) Die natürlichen Pflanzenfamilien. 2nd ed. Vol. 3. Verlag von Wilhelm Engelmann, Leipzig, pp. 1-374.

Shubert, E. \& Gärtner, G. 2015. Nonmotile coccoid and colonial green algae. In Wehr, J. D., Sheath, R. G. \& Kociolek, J. P. (Eds.) Freshwater Algae of the United States: Ecology and Classification. 2nd ed. Academic Press, Amsterdam, pp. 315-373.

Skuja, H. 1964. Grundzüge der Algenflora und Algenvegetation der Fjeldgegenden um Abisko in Schwedisch-Lap- pland. Nova Acta Regia Soc. Sci. Ups. Ser. IV 18:1-465.

Smith, G. M. 1933. The fresh-water algae of the United States. McGraw-Hill Book Co., New York, 716 pp.

Smith, G. M. 1950. The fresh-water algae of the United States. 2nd ed. McGraw-Hill Book Co., New York, 719 pp.

Stafleu, F. A. \& Mennega, E. A. 1993. Taxonomic literature. Suppl. II: Be-Bo. Koeltz Scientific Books, Königstein, 464 pp.

Trainor, F. R. \& Bold, H. C. 1953. Three new unicellular Chlorophyceae from soil. Am. J. Bot. 40:758-767.

Trainor, F. R. \& Hilton, R. L. Jr. 1964. A new species of Hormotila from a Connecticut soil. Phycologia 4:99-104.

West, G. S. 1904. A treatise on the British freshwater algae. University Press, Cambridge, $372 \mathrm{pp}$.

Wille, N. 1897. Tetrasporaceae. In Engler, A. \& Prantl, K. (Eds.) Die Natürlichen Pflanzenfamiliennebst ihren Gattungen und Wichtigeren Arten, Insbesondere den Nutzpflanzen, unter Mitwirkung Zahlreicher hervorragender Fachgelehrten Begründet I. Teil, Abteilung 2. W. Engelmann, Leipzig, pp. 43-51. 